\title{
Insulin Infusion in Conscious Dogs
}

\author{
EFFECTS ON SYSTEMIC AND CORONARY HEMODYNAMICS, REGIONAL \\ BLOOD FLOWS, AND PLASMA CATECHOLAMINES
}

\author{
Chang-seng liang, John U. Doherty, Robert Faillace, Kishio Maekawa, \\ Stephanie Arnold, Haralambos Gavras, and William B. Hood, Jr., \\ Departments of Medicine and Pharmacology, and the Cardiovascular \\ Institute, Boston University School of Medicine, Department of Cardiology \\ and Thorndike Memorial Laboratory, Boston City Hospital, Boston, \\ Massachusetts 02118
}

A B S T R A C T Cardiovascular actions of insulin were studied by intravenous infusions of insulin ( 4 and 8 $\mathrm{mU} / \mathrm{kg}$ per $\mathrm{min}$ ) in normal conscious dogs. This resulted in increases in cardiac output, heart rate, and left ventricular derivative of pressure with respect to time $(d P / d t)$ and $d P / d t / P$, as blood glucose was reduced. The inotropic and chronotropic effects of insulin were not related to hypoglycemia, as they persisted even when blood glucose was restored to control values or when it was prevented from falling by a simultaneous infusion of glucose. These cardiac effects were accompanied by increases in plasma catecholamines, and were abolished by propranolol pretreatment. Both plasma epinephrine and norepinephrine increased during insulin hypoglycemia, but only norepinephrine increased during insulin infusion when euglycemia was maintained.

Mean arterial blood pressure did not change significantly during insulin hypoglycemia, but rose if euglycemia was maintained, probably due to the selective increase in norepinephrine in the latter condition. A pressor response also occurred in propranolol-pretreated dogs during insulin hypoglycemia, but was abolished when the animals also had been pretreated

This study was presented in part at the 53rd Annual Scientific Meetings of the American Heart Association in Miami Beach, FL, 16 November 1980, the 30th Annual Scientific Session of the American College of Cardiology in San Francisco, CA, 18 March 1981, and the 38th Annual Meeting of the American Federation for Clinical Research in San Francisco, CA, 26 April 1981.

Address reprint requests to Dr. Liang, Boston University School of Medicine.

Received for publication 6 April 1981 and in revised form 29 December 1981. with phentolamine, indicating that the vasoconstrictor action of insulin was mediated via alpha adrenergic receptors.

Insulin infusion increased left ventricular work and myocardial blood flow in dogs with and without hypoglycemia. Myocardial blood flow, however, did not change significantly during insulin infusion in dogs pretreated with propranolol. As propranolol also diminished the inotropic response, it appears that the increase in myocardial blood flow caused by insulin in the normal dog is causally related to the increased myocardial metabolic demand.

Insulin also produced vasomotor effects on other vascular beds. In skeletal muscle, blood flow was increased under all study conditions, except during insulin hypoglycemia after propranolol-pretreatment when unopposed alpha-mediated vasoconstriction was present. The persistent increase in flow during both alpha and beta adrenergic blockade suggests that insulin has a direct dilator effect on skeletal muscle vasculature. In the adrenal gland, flow was increased except during euglycemia, when no rise in plasma epinephrine was observed, suggesting coupling between adrenal flow and catecholamine release. In the splanchnic bed, flow was decreased during euglycemia, when plasma norepinephrine rose, and during beta adrenergic blockade with propranolol, when unopposed alpha-mediated vasoconstriction also predominated. A similar pattern was found in the kidney, except that renal blood flow also fell after combined alpha and beta adrenergic blockade. The results show that the vasomotor effects on regional flows are mediated both via adrenergic mechanisms, and in the case of skeletal muscle and kidney, via mechanisms unrelated to sympathetic stimulation. 


\section{INTRODUCTION}

Insulin, apart from its effects on carbohydrate metabolism and on ion flux, has been shown to have effects on both the heart and the peripheral vasculature. The cardiovascular responses associated with the acute administration of insulin in man include increases in heart rate (1-3), cardiac output $(1,4)$, and forearm blood flow (5-9). These are thought to be caused by sympathetic stimulation resulting from insulin-induced hypoglycemia (10-13). However, the cardiovascular effects of insulin cannot be entirely the consequence of hypoglycemia, as they occur even when the blood glucose concentration does not decline below normal fasting values $(3,14)$. Furthermore, it has been shown that sympathetic stimulation, as evidenced by an increase in plasma norepinephrine, may occur after insulin administration even in the absence of hypoglycemia (14-16). These observations suggest that insulin may exert a stimulatory action on the sympathetic nervous system independent of hypoglycemia.

Insulin has been shown to exert a direct inotropic effect, independent of glucose levels and beta adrenergic receptors, in isolated cardiac muscle preparations (17) and in developing piglet (18) or lamb (19) myocardium. However, Lucchesi et al. (20) have failed to find a direct inotropic effect of insulin in either canine isolated papillary muscles or intact dog heart unless the myocardium was first depressed by propranolol, severe hypoxia, or prolonged incubation. Furthermore, very large doses of insulin were used in these isolated organs and anesthetized animal preparations. No studies have been performed in intact conscious animals. Thus, the physiologic significance of the direct inotropic action of insulin on the heart is not known.

The purpose of this study was to assess the systemic and regional blood flow responses to insulin in the conscious dog, using doses of insulin similar to those used by Rowe et al. (16) in normal volunteers. We also carried out experiments to determine the relative contributions of sympathetic stimulation and of the direct inotropic action of insulin in mediating the cardiovascular responses. The role of the sympathetic nervous system was assessed by measuring plasma catecholamines and by pretreating the animals with alpha and beta adrenergic blocking agents. In addition, blood glucose was maintained constant in some animals so that the effects of insulin in the absence of hypoglycemia could be ascertained.

\section{METHODS}

Surgical procedure and measurements. Purebred adult beagles of both sexes weighing $6.5-15.2 \mathrm{~kg}$ were used. The animals were anesthetized with sodium pentobarbital (25 $\mathrm{mg} / \mathrm{kg}$, i.v.) and mechanically ventilated using a Harvard respirator (Harvard Apparatus Co., Inc., S. Natick, MA). A sterile left thoracotomy was performed via the fifth intercostal space for insertion of heparin-filled Tygon catheters (i.d., $1.02 \mathrm{~mm}$; Norton Co., Plastics \& Synthetics Div., Akron, $\mathrm{OH})$ in the main pulmonary artery, left atrium, and the descending thoracic aorta. The catheters were then exteriorized through the interscapular space and secured at the back of the dog's neck. After the thoracotomy was closed, the animal was allowed to recover for 2 to $3 \mathrm{wk}$ before the experiment. Veterinary procaine penicillin $\mathrm{G}(400,000 \mathrm{U})$ and dihydrostreptomycin (500 mg, Combiotic, Pfizer Chemicals Div., New York) were given intramuscularly daily for $10 \mathrm{~d}$ postoperatively.

At the time of experiment, the chronically indwelling catheters were connected to Statham P23Db pressure transducers (Statham Instruments, Inc., Oxnard, CA) and an 8channel Brush 480 recorder (Gould Inc., Instruments Div., Cleveland, $\mathrm{OH}$ ) to measure aortic and left atrial pressures. Heart rate was measured by an electrocardiographic monitor and cardiotachometer. A Millar transducer-tip catheter (Millar Instruments Inc., Houston, TX) was introduced into the left ventricle via a femoral artery for measuring left ventricular pressure and the first derivative of the left ventricular pressure with respect to time $(d P / d t)^{1}$ was obtained by an electronic differentiator. The $d P / d t$ during isovolumic contraction at a left ventricular developed pressure of 50 $\mathrm{mm} \mathrm{Hg}$ was used to derive left ventricular $d P / d t / P$, which is an index of left ventricular contractility (21). This index was calculated using a PDP 11/10 minicomputer (Digital Equipment Corp., Marlboro, MA). In addition, a French 7 catheter was introduced into the coronary sinus via an external jugular vein under fluoroscopic guidance.

Cardiac output was determined by a dye-dilution technique using indocyanine green (Cardio-Green, Hynson Westcott \& Dunning Inc., Baltimore, MD) injected into the pulmonary artery and a Gilford model 140 cardiac output system (Gilford Instrument Laboratories Inc., Oberlin, $\mathrm{OH}$ ) Regional organ blood flows were measured by a modification (22) of the radioactive microsphere method of Rudolph and Heymann (23). 500,000-1,000,000 microspheres, $15 \pm 3 \mu \mathrm{m}$ in diameter, and labeled with cerium-141, tin-113, ruthenium-103, or scandium -46 at $10 \mathrm{mCi} / \mathrm{g}$, sp act, were injected into the left atrial catheter, followed immediately by a flush of $10 \mathrm{ml}$ of normal saline over a $30-\mathrm{s}$ period. Arterial reference blood was withdrawn with a Harvard pump (Harvard Apparatus Co., Inc.) at a rate of $7.75 \mathrm{ml} / \mathrm{min}$, beginning 10 $\mathrm{s}$ before the injection of microspheres and continuing for 80 $s$ thereafter. The content of radioactivity in each organ was measured in a Packard gamma spectrometer with a model 9012 multichannel analyzer (Packard Instrument Co., Inc. Downers Grove, IL) at the appropriate gamma photon energy for each of the radionuclides. Absolute blood flow to each organ was calculated by the reference sample method on a PDP-11/10 minicomputer (22). Mean aortic blood pressure was divided by cardiac output or organ blood flow to yield the total peripheral or regional organ vascular resistance.

Blood samples were obtained simultaneously from aorta, pulmonary artery, and coronary sinus for measuring oxygen content on a Lex- $\mathrm{O}_{2}$-Con oxygen analyzer (Lexington Instruments Corp., Waltham, $\mathrm{MA}$ ). Blood $\mathrm{pH}, \mathrm{PO}_{2}$, and $\mathrm{PCO}_{2}$ were measured with a Radiometer PHM 71 Acid Base An-

${ }^{1}$ Abbreviation used in this paper: $d P / d t$, derivative of pressure with respect to time. 
alyzer (Rainin Instrument Co. Inc., Woburn, MA). Arterial blood samples also were taken for measuring blood glucose, sodium, potassium, and plasma catecholamines. Blood glucose was determined using a glucose oxidase hydrogen peroxide probe on a YSI model 23A glucose analyzer (Yellow Springs Instrument Co., Yellow Springs, $\mathrm{OH}$ ), and plasma sodium and potassium by a flame photometer. Plasma epinephrine and norepinephrine were measured by a radioenzymatic method (24), using the enzyme catechol-O-methyltransferase and $S$-adenyl-L-methionine- $\left(\left[{ }^{3} \mathrm{H}\right]\right.$ methyl). In addition, lactate (25) and pyruvate (26) were measured in the arterial and coronary sinus blood. Myocardial oxygen consumption, coronary vascular resistance, left ventricular work, total body oxygen consumption and myocardial use of glucose, lactate, and pyruvate were calculated by conventional formulae (22).

Experimental protocols. 35 animals were divided equally into five experimental groups (groups 1-5), all of which received insulin infusion. All experiments involved a $20-\mathrm{min}$ control period followed by the administration of pure pork monocomponent, glucagon-free, insulin (Eli Lilly and Co., Indianapolis, IN), intravenously. Insulin was administered intravenously as an initial bolus injection $(50 \mathrm{mU} / \mathrm{kg})$ followed by successive infusions at rates of 4 and $8 \mathrm{mU} / \mathrm{kg}$ per min, using a Harvard infusion pump. Insulin was diluted in normal saline and its concentration was adjusted so that for each animal both doses of insulin could be delivered at a constant rate of $0.19 \mathrm{ml} / \mathrm{min}$. Each dose was infused for 30 min, except in a group of seven dogs (group 1 ) in which the second infusion was allowed to continue for an additional $30 \mathrm{~min}$. During this time blood glucose was restored to control values by a simultaneous infusion of $50 \%$ glucose, using a glucose clamp technique (27). The role of the autonomic nervous system in mediating the responses to insulin was studied in groups 2 and 3 . Beta adrenergic receptor blockade was produced in both groups by pretreatment with propranolol (0.5 mg/kg, i.v., Ayerst, McKenna, \& Harrison Ltd., Montreal, Canada) 30 min before the control measurements were obtained. In addition, alpha adrenergic receptor blockade was produced in group 3 by a continuous intravenous infusion of phentolamine hydrochloride $(8 \mu \mathrm{g} / \mathrm{kg}$ per min, Ciba-Geigy Corp., Pharmaceuticals Division, Summit, NJ), beginning $30 \mathrm{~min}$ before the control period, at a rate of 0.1 $\mathrm{ml} / \mathrm{min}$ by a Harvard infusion pump. Degrees of alpha and beta receptor blockade were determined by comparing the responses of mean aortic blood pressure and heart rate with injections of serial doses of norepinephrine and isoproterenol, before the administration of these agents and at the end of the experiments.

In groups 4 and 5, 50\% glucose was infused throughout the entire period of insulin infusion to prevent blood glucose from falling, using the glucose clamp technique. The effects of insulin euglycemia were studied in group 4 that received insulin infusion along with $50 \%$ glucose infusion, whereas in group 5 insulin and glucose infusions were begun $30 \mathrm{~min}$ after propranolol $(0.5 \mathrm{mg} / \mathrm{kg}, \mathrm{i} . \mathrm{v}$. $)$ pretreatment. In addition, a control group of five normal dogs was included for comparison. These animals received a continuous intravenous infusion of normal saline $(0.19 \mathrm{ml} / \mathrm{min})$. Otherwise, the experimental protocols were identical to those for the five groups that received insulin infusion.

Systemic hemodynamic measurements and blood glucose concentrations were obtained at 5-min intervals during both the control period and insulin (or normal saline) infusion. Averages were obtained from triplicate measurements of each hemodynamic variable during the control period. The values from each dog were then averaged and these are re- ported in Results. Regional blood flows, blood oxygen contents, electrolytes, and blood metabolites were obtained during the control period and during the last $5 \mathrm{~min}$ of each phase of insulin (or normal saline) infusion in all groups, whereas plasma catecholamines were measured only in those groups that were not pretreated with adrenergic blocking agents.

At the end of the experiment, the animal was killed by injecting a lethal dose of sodium pentobarbital. The heart, brain, lungs, stomach, small intestine, large intestine, liver, pancreas, spleen, adrenal glands, kidneys, femoral muscle, femur, and skin were removed, cleaned, weighed, and prepared for radioactivity counting for the calculation of regional blood flows.

Statistical analysis. The experimental results are presented in mean $\pm \mathrm{SE}$. The statistical significance of the differences among the groups was determined by two-way analysis of variance for independent groups with trend measures (28). Dunnett's test (29) was used to determine the statistical significance of differences between the control value and the serial repeated measurements during insulin infusion in each group. Student's $t$ test was used to analyze the difference between two means in each group. Changes are considered statistically significance if $P$ values are $<0.05$.

\section{RESULTS}

Systemic hemodynamic responses to insulin hypoglycemia. Fig. 1 shows that insulin administration decreased blood glucose and increased cardiac output and left ventricular $d P / d t$ in the normal dog (group $1,10 \pm 1 \mathrm{~kg}$ ), and that these changes persisted even after blood glucose had been restored to control values by glucose infusion during the last $30 \mathrm{~min}$ of insulin infusion. Heart rate, left ventricular $d P / d t / P$, and aortic pulse pressure $(50 \pm 2-59 \pm 2 \mathrm{~mm} \mathrm{Hg})$ also increased during insulin infusion, but mean aortic blood pressure did not change significantly (Fig. 2). As a result, the calculated total peripheral vascular resistance fell. Left atrial pressure did not change significantly during insulin infusion $(5.2 \pm 0.9-4.3 \pm 1.2$ $\mathrm{mm} \mathrm{Hg}$ )

Fig. 2 also shows the systemic hemodynamic responses to insulin hypoglycemia in groups 2 and 3 that had been pretreated with adrenergic blocking agents. Significant beta adrenergic receptor blockade was evidenced by the increase in the dose of isoproterenol required to increase heart rate 25 beats/min from $1.5 \pm 0.2 \mu \mathrm{g}$ before propranolol administration to $36.8 \pm 5.3 \mu \mathrm{g}$ after propranolol administration in group $2(12 \pm 1 \mathrm{~kg})$, and from $1.7 \pm 0.4$ to $49.6 \pm 8.5 \mu \mathrm{g}$ in group $3(9 \pm 1 \mathrm{~kg})$. Significant alpha adrenergic receptor blockade was produced by phentolamine infusion in group 3, as evidenced by the increase in the dose of norepinephrine needed to raise mean aortic blood pressure $25 \mathrm{~mm} \mathrm{Hg}$ from $5.5 \pm 0.7 \mu \mathrm{g}$ before phentolamine infusion to $24.2 \pm 4.2 \mu \mathrm{g}$ at the end of the experiment.

Fig. 2 shows that the effects of insulin on cardiac 


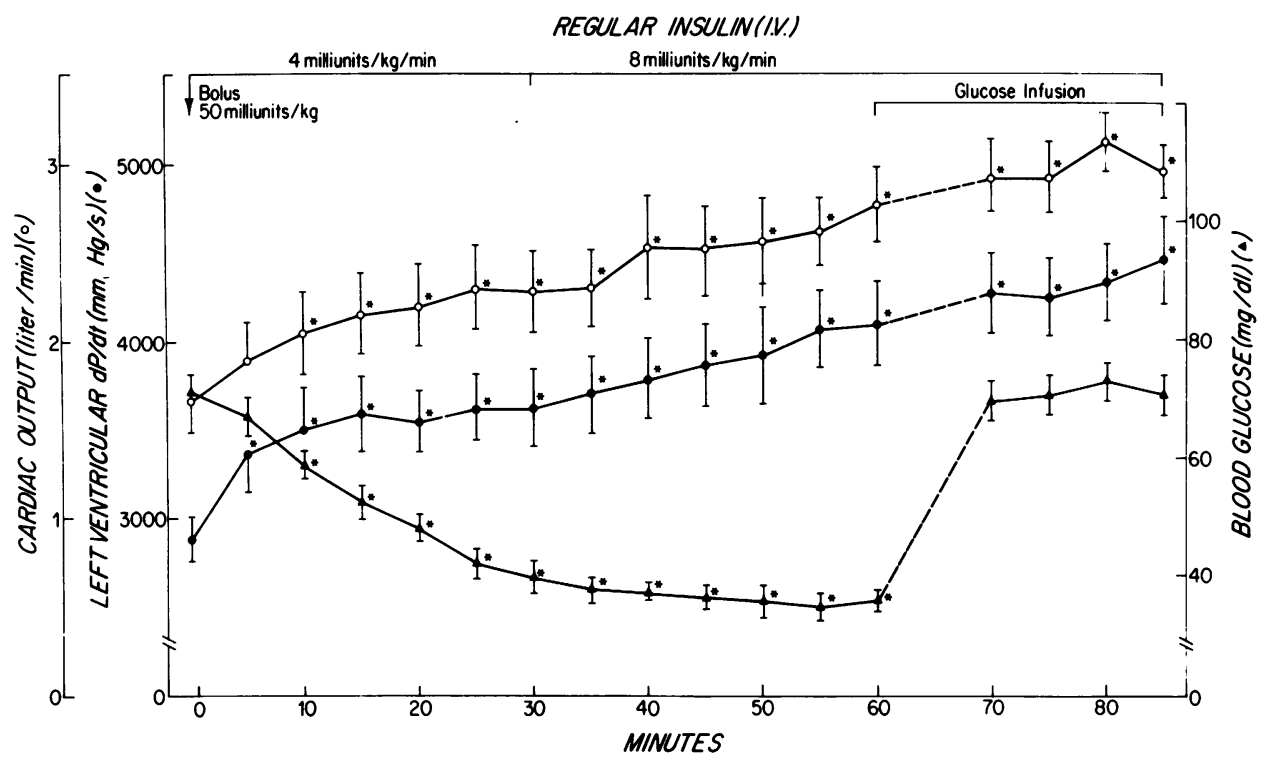

Figure 1 Effects of insulin infusion on cardiac output, left ventricular $d P / d t$, and blood glucose in seven conscious normal dogs (group 1). Bars show $\mathrm{SE} .^{\circ}=$ values that are significantly different from the base-line value before insulin infusion. Both cardiac output and left ventricular $d P / d t$ increased as blood glucose fell, and remained elevated even after blood glucose had been restored to base-line values by glucose infusion.

output, heart rate, left ventricular $d P / d t$, and $d P / d t /$ $P$ were abolished by propranolol pretreatment in both groups 2 and 3 . The increase in aortic pulse pressure produced by insulin was also abolished in group 2 $(44 \pm 3-46 \pm 3 \mathrm{~mm} \mathrm{Hg})$ and group $3(40 \pm 4-36 \pm 3 \mathrm{~mm}$ $\mathrm{Hg}$ ). Furthermore, unlike group 1 , mean aortic pressure and total peripheral vascular resistance increased in group 2 during insulin infusion, presumably from unopposed alpha adrenergic stimulation. These vascular effects of insulin were not present in group 3 dogs that received phentolamine infusion. Left atrial pressure increased from $6.0 \pm 1.2$ to $9.9 \pm 2.4 \mathrm{~mm} \mathrm{Hg}$ in group 2, but did not change significantly in group 3.

Arterial blood $\mathrm{pH}$ and blood gas tensions were within the normal range in these experiments. Total body oxygen consumption increased in group 1 from $69 \pm 5 \mathrm{ml} / \mathrm{min}$ during the control period to $101 \pm 9 \mathrm{ml} /$ min during the infusion of the higher dose of insulin, but did not change significantly in either group 2 $(91 \pm 7-97 \pm 9 \mathrm{ml} / \mathrm{min})$ or group $3(83 \pm 10-79 \pm 9 \mathrm{ml} /$ min). Plasma potassium decreased significantly in all three groups (from $3.3 \pm 0.2$ to $2.6 \pm 0.1 \mathrm{meq} / \mathrm{liter}$ in group 1 , from $3.3 \pm 0.1$ to $2.9 \pm 0.1 \mathrm{meq} / \mathrm{liter}$ in group 2 , and from $3.5 \pm 0.1$ to $2.6 \pm 0.1 \mathrm{meq} / \mathrm{liter}$ in group 3 ), but there was no change in plasma sodium concentration.

Plasma norepinephrine and epinephrine increased as blood glucose decreased during insulin infusion
(Fig. 3). However, when euglycemia was restored by glucose infusion to control values, plasma catecholamine levels decreased. Nevertheless, plasma norepinephrine was still significantly higher than that before insulin administration.

Systemic hemodynamic responses to insulin euglycemia. Cardiac output, heart rate, and left ventricular $d P / d t$ and $d P / d t / P$ increased (Fig. 4) in group $4(12 \pm 1 \mathrm{~kg})$ in which the blood glucose level was maintained at base-line levels throughout the experiments by administering glucose during insulin infusion (Fig. 5). However, the increase in cardiac output $(0.59 \pm 0.08$ liter/min) was significantly smaller than that in group 1 with insulin hypoglycemia $(0.93 \pm 0.09 \mathrm{liter} / \mathrm{min}, \mathrm{Fig}$. 6 ). Furthermore, in this group mean aortic blood pressure increased slightly during insulin infusion (Fig. 4), and total peripheral vascular resistance decreased to a smaller extent than that in group 1 (Fig. 6). These cardiovascular changes produced by insulin during euglycemia were abolished by propranolol pretreatment in group $5(13 \pm 1 \mathrm{~kg})$. In contrast to reduction in total peripheral vascular resistance in group 4 , total peripheral vascular resistance increased slightly toward the end of insulin infusion in group 5. Beta receptor blockade was verified in group 5 by serially administered doses of isoproterenol; the dose of isoproterenol required to increase heart rate 25 beats/ min changed from $1.9 \pm 0.6 \mu \mathrm{g}$ before propranolol pretreatment to $40.9 \pm 5.1 \mu \mathrm{g}$ at the end of the experiment. 


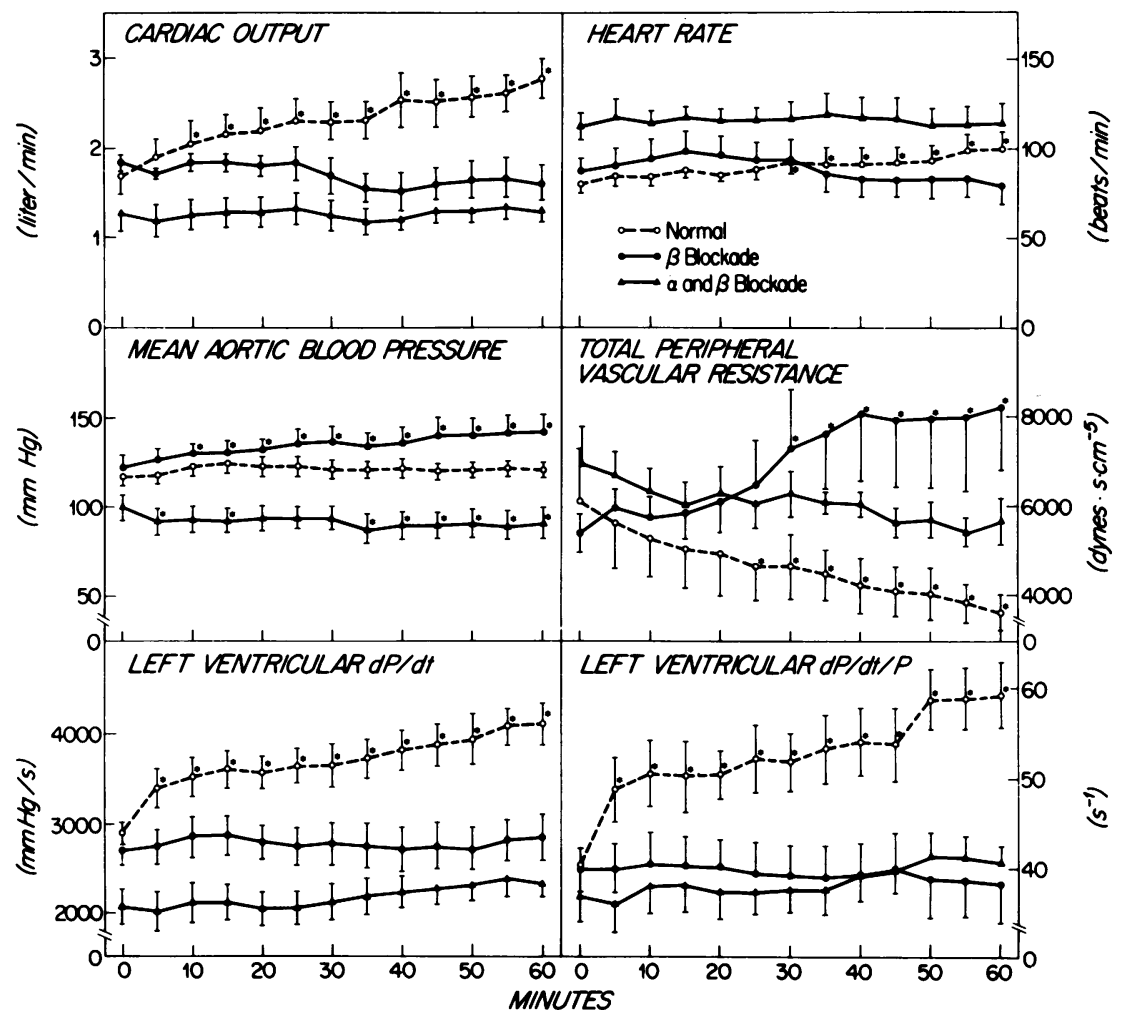

Figure 2 Changes in cardiac output, heart rate, mean aortic blood pressure, total peripheral vascular resistance, left ventricular $d P / d t$, and $d P / d t / P$ in seven normal dogs (broken lines, group 1), seven dogs pretreated with propranolol (solid lines and circles, group 2), and seven dogs pretreated with both propranolol and phentolamine (solid lines and triangles, group 3 ). All these animals responded with hypoglycemia to insulin infusion. See legend to Fig. 1 for additional details.

Aortic pulse pressure did not change significantly in either group 4 (58 $\pm 3-62 \pm 3 \mathrm{~mm} \mathrm{Hg}$ ) or group 5 (47 $44-$ $48 \pm 4 \mathrm{~mm} \mathrm{Hg}$ ).

Insulin infusion increased total body oxygen consumption $(85 \pm 5-116 \pm 12 \mathrm{ml} / \mathrm{min})$ and decreased plasma potassium $(3.4 \pm 0.1-2.8 \pm 0.1 \mathrm{meq} / \mathrm{liter})$ in group 4. Plasma potassium also decreased significantly from $3.5 \pm 0.1$ to $2.6 \pm 0.1 \mathrm{meq} / \mathrm{liter}$ in group 5 , but the change in total body oxygen consumption $(94 \pm 10$ $108 \pm 7 \mathrm{ml} / \mathrm{min}$ ) was not statistically significant. Moreover, in group 4 plasma norepinephrine significantly increased during the infusion of the lower dose of insulin, but did not increase further as the dose of insulin doubled. Plasma epinephrine, however, did not significantly increase during insulin euglycemia (Fig. 5).

Coronary hemodynamic responses to insulin. Tables I and II show that insulin increased left ventricular blood flow, left ventricular work, and myocardial oxygen consumption, and decreased coronary vascular resistance in the normal dog with both hypoglycemia (group 1) and euglycemia (group 4), whereas myocardial oxygen extraction did not change in either group. In contrast, none of these parameters were significantly altered by insulin in dogs pretreated with propranolol (groups 2 and 5) or with propranolol plus phentolamine (group 3).

Effects of insulin on myocardial metabolism. Tables III and IV show that insulin affected the myocardial use of glucose, lactate, and pyruvate. In group 1 , insulin diminished the arterial concentration of glucose and increased that of pyruvate. Arterial lactate did not change significantly. Rates of myocardial use of glucose, lactate, and pyruvate were increased; however, as the arterial glucose concentration decreased to a nadir during the infusion of the higher dose of insulin, the increase in the myocardial use of glucose was no longer statistically significant.

In groups 2 and 3, the arterial glucose also decreased during insulin infusion, but unlike group 1 , it was accompanied by a decrease in arterial pyruvate. The 


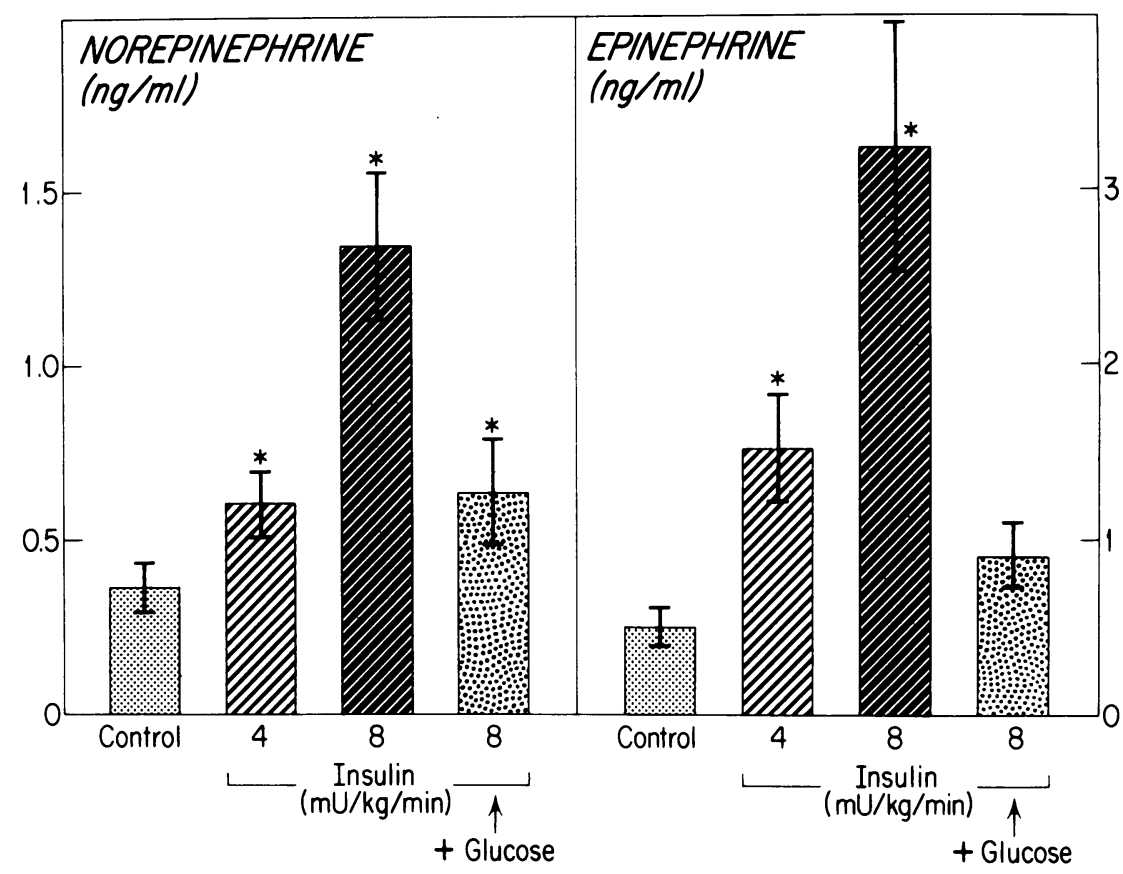

FIGURE 3 Changes in plasma norepinephrine and epinephrine during infusions of insulin and insulin plus glucose in seven normal dogs whose blood glucose decreased during insulin infusion but was restored to control values by simultaneous infusions of insulin and glucose (group 1, see Fig. 1). See legend to Fig. 1 for additional details.

arterial lactate did not change significantly. Myocardial use of glucose increased slightly in both groups, although the increase was statistically significant in group 3 only. In contrast, the use of pyruvate and lactate tended to decrease, although only the decrease in pyruvate was statistically significant.

The arterial concentrations of glucose, lactate, and pyruvate did not change significantly in the normal dog during insulin euglycemia (group 4). Myocardial use of glucose and lactate increased during insulin infusion, but that of pyruvate did not change significantly. In group 5, myocardial use of glucose increased, and arterial concentration and myocardial use of pyruvate decreased, while neither lactate concentration nor myocardial use of lactate changed significantly.

Arterial and coronary sinus lactate/pyruvate ratios did not change significantly in any of the groups during insulin infusion. In group 1 , the arterial and coronary sinus blood lactate/pyruvate ratios were $8.9 \pm 0.9$ and $12.1 \pm 1.6$ before insulin administration, and were $9.8 \pm 0.5$ and $12.7 \pm 1.1$, respectively, during insulin infusion $(8 \mathrm{mU} / \mathrm{kg}$ per $\mathrm{min})$.

Effects of insulin on regional blood flows. Insulin increased blood flow to the right and left ventricles, adrenal glands, and skeletal muscle, and decreased bronchial blood flow in group 1 (Table V, Fig. 7). The infusion of glucose in this group abolished the increase in adrenal blood flow and decreased the fall in bronchial blood flow, but myocardial and skeletal muscle blood flows remained elevated despite the return of blood glucose to control values. These increases in blood flow were associated with corresponding decreases in skeletal muscle, coronary, and adrenal vascular resistances. However, neither renal nor splanchnic blood flow was affected by insulin infusion (Fig. 7).

In group 2, insulin infusion had no effect on skeletal muscle blood flow or vascular resistance. It increased adrenal blood flow and decreased blood flow to kidneys and splanchnics. Simultaneously, adrenal vascular resistance fell, and renal and splanchnic vascular resistances increased (Fig. 8). The infusion of phentolamine in group 3 abolished the effects of insulin on the splanchnic vasculature. However, the effects of insulin on the kidneys and adrenal glands persisted (Fig. 9). Unlike group 2, insulin increased skeletal muscle blood flow and decreased vascular resistance in skeletal muscle in group 3.

Skeletal muscle blood flow also increased during insulin euglycemia in groups 4 and 5 (Figs. 10 and 11 ), but unlike the first three groups with insulin hypoglycemia, adrenal blood flow was unchanged. Furthermore, renal and splanchnic blood flows decreased 


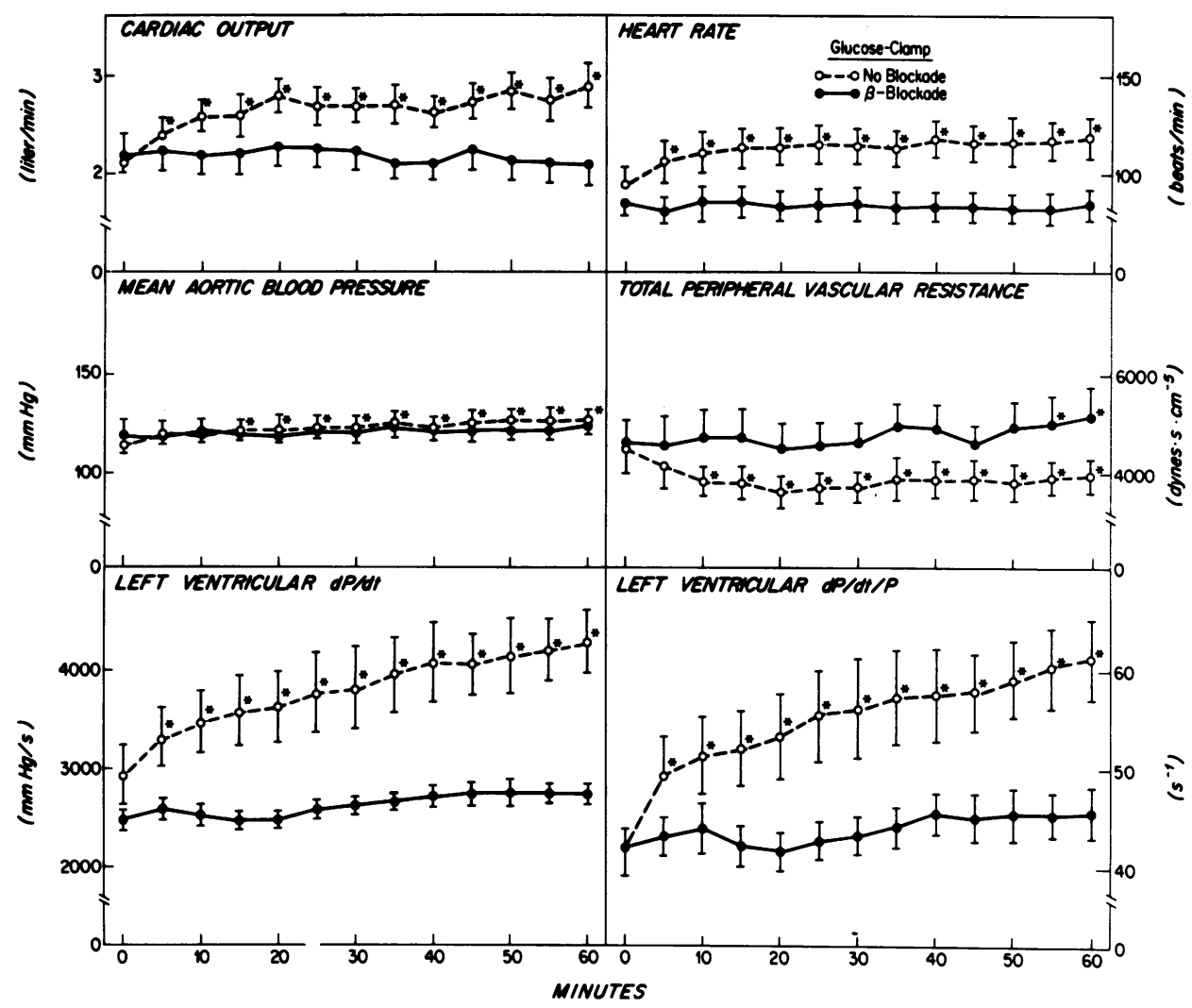

Figure 4 Changes in cardiac output, heart rate, mean aortic blood pressure, total peripheral vascular resistance, left ventricular $d P / d t$, and $d P / d t / P$ during insulin infusion in seven normal dogs with euglycemia that received $50 \%$ glucose infusion by a glucose-clamp technique during insulin infusion (broken lines, group 4), and seven other dogs that also were kept euglycemic but had been treated with propranolol before insulin infusion (solid lines, group 5). See legend to Fig. 1 for additional details.

and vascular resistances increased in both groups. Other regional organ blood flows did not change significantly.

Changes in hemodynamics and plasma catecholamines in the control group. Administration of normal saline in 5 normal dogs $(11 \pm 1 \mathrm{~kg})$ produced no significant changes in systemic or regional hemodynamics, nor did it increase plasma norepinephrine $(0.35 \pm 0.05-0.30 \pm 0.06 \mathrm{ng} / \mathrm{ml})$ or epinephrine $(0.67 \pm 0.15-0.60 \pm 0.11 \mathrm{ng} / \mathrm{ml})$.

\section{DISCUSSION}

Sympathetic stimulation by insulin. Our present study confirms earlier findings $(14,15)$ that insulin hypoglycemia increases plasma norepinephrine and epinephrine. This probably is due to release of adrenal catecholamines from an action of hypoglycemia on the central nervous system $(30,31)$. However, our study further demonstrates that when euglycemia was main- tained, insulin still caused a small increase in plasma norepinephrine, without an increase in plasma epinephrine. Our results are like those found in normal human volunteers during infusions of similar doses of insulin (16). The absence of an increase in plasma epinephrine in euglycemic man and animals during insulin infusion suggests that adrenal stimulation may be absent when blood glucose levels are maintained, and suggests also that the small rise in norepinephrine probably results from the release of norepinephrine from sympathetic nerve endings. However, the mechanism by which insulin stimulates the sympathetic nervous system independent of hypoglycemia is unclear. Gundersen and Christensen (32) suggested that it was related to a reflex compensation to hypovolemia because insulin decreased both plasma volume and the intravascular pool of albumin. Subsequent investigators (33), however, failed to confirm this effect of insulin on plasma volume. Moreover, intravascular volume probably did not decrease markedly in our 


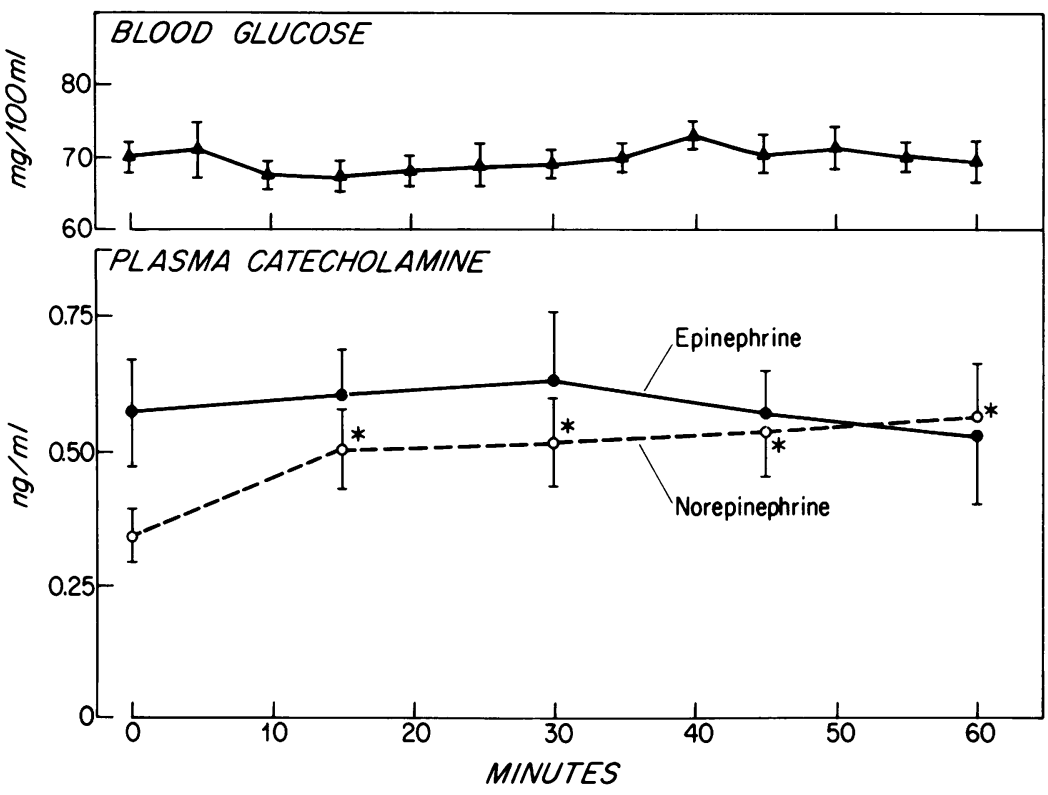

Figure 5 Effects of insulin euglycemia on plasma catecholamines in group 4. See legend to Fig. 1 for additional details.

experiments because left atrial pressure did not decrease. Alternatively, Pereda et al. (34) have shown that the sympathetic nervous system can be stimulated by a direct action of insulin on the central nervous system. They demonstrated that both cardiac output

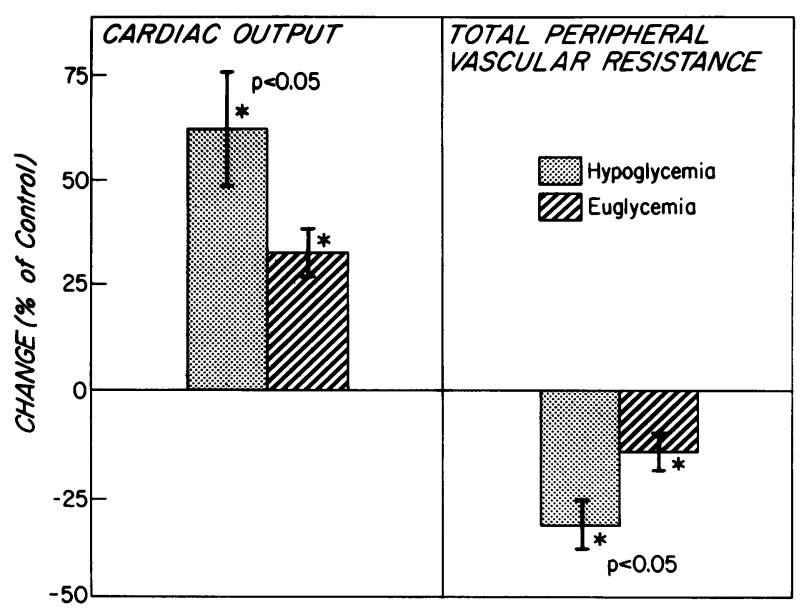

Figure 6 Differences in cardiac output and total peripheral vascular resistance responses to insulin infusion $(8 \mathrm{mU} / \mathrm{kg}$ per $\mathrm{min}$ ) between group 1 (with hypoglycemia) and group 4 (with euglycemia). $n=7$ in each group. ${ }^{\circ}$ indicate that the changes produced by insulin are statistically significant in each group, and the $P$ values indicate that the differences in the responses between the two groups are also statistically significant. and arterial pressure increased after the intracarotid administration of small doses of insulin, which had no effect when injected into a peripheral vein. Still another possibility is that sympathetic stimulation may occur as a result of an increase in tissue metabolic rate $(22,35)$, a condition also caused by insulin administration (36).

Cardiac effects of insulin. Insulin exerts significant cardiovascular effects in normal conscious dogs. Our data not only support earlier findings in man that insulin increases cardiac output and heart rate (1-4), but establish that the increase in cardiac output is related, at least in part, to increased myocardial contractility, as evidenced by the rises in left ventricular $d P / d t$ and $d P / d t / P$. The increase in myocardial contractility is independent of changes in blood glucose, as it occurred even in absence of hypoglycemia (group 4).

The findings that insulin increased plasma catecholamines and absence of insulin-induced changes in heart rate, left ventricular $d P / d t$, and $d P / d t / P$ after propranolol pretreatment, suggest that the positive inotropic and chronotropic effects of insulin are mediated via the beta adrenergic receptors. Our data further indicate that, at the doses we used, insulin has little direct inotropic action on the heart. The data do not necessarily refute the fact that insulin may have direct inotropic effects when much larger doses are used $(15,17-20)$. On the other hand, the direct inotropic action of insulin has not been generally accepted (37); in fact, in some studies insulin has been shown 
TABLE I

Effects of Insulin Hypoglycemia on Coronary Hemodynamics

\begin{tabular}{cccccc}
\hline Insulin & $\begin{array}{c}\text { Left ventricular } \\
\text { blood flow }\end{array}$ & $\begin{array}{c}\text { Myocardial } \\
\mathrm{O}_{2} \text { extraction }\end{array}$ & $\begin{array}{c}\text { Myocardial } \mathrm{O}_{2} \\
\text { consumption }\end{array}$ & $\begin{array}{c}\text { Coronary vascular } \\
\text { resistance }\end{array}$ & $\begin{array}{c}\text { Left ventricular } \\
\text { work }\end{array}$ \\
\hline $\mathrm{mU} / \mathrm{kg} / \mathrm{min}$ & $\mathrm{ml} / \mathrm{l} 00 \mathrm{~g} / \mathrm{min}$ & $\%$ & $\mathrm{ml} / 100 \mathrm{~g} / \mathrm{min}$ & $\mathrm{mm} \mathrm{Hg} /(\mathrm{ml} / 100$ & $\mathrm{gg} / \mathrm{min})$
\end{tabular}

Group 1 No pretreatment

$\begin{array}{lllclr}0 & 103 \pm 12 & 71 \pm 5 & 8.2 \pm 1.1 & 1.22 \pm 0.15 & 6.0 \pm 0.5 \\ 4 & 124 \pm 23 & 77 \pm 5 & 11.6 \pm 1.9^{\circ} & 1.09 \pm 0.14 & 8.7 \pm 0.8^{\circ} \\ 8 & 141 \pm 20^{\circ} & 70 \pm 5 & 11.7 \pm 1.7^{\circ} & 0.92 \pm 0.13^{\circ} & 10.0 \pm 0.8^{\circ}\end{array}$

Group 2 Propranolol pretreatment

$\begin{array}{llllll}0 & 80 \pm 6 & 83 \pm 2 & 9.1 \pm 0.9 & 1.48 \pm 0.15 & 6.6 \pm 0.5 \\ 4 & 89 \pm 11 & 77 \pm 5 & 9.8 \pm 1.4 & 1.55 \pm 0.17 & 7.1 \pm 0.7 \\ 8 & 85 \pm 12 & 77 \pm 5 & 9.4 \pm 1.0 & 1.59 \pm 0.21 & 6.4 \pm 0.7\end{array}$

Group 3 Propranolol plus phentolamine pretreatment

\begin{tabular}{llllll}
0 & $72 \pm 10$ & $88 \pm 1$ & $7.8 \pm 0.7$ & $1.50 \pm 0.23$ & $4.8 \pm 0.9$ \\
4 & $64 \pm 8$ & $85 \pm 2$ & $8.4 \pm 1.6$ & $1.58 \pm 0.20$ & $4.7 \pm 1.0$ \\
8 & $72 \pm 9$ & $83 \pm 2$ & $6.4 \pm 0.5$ & $1.32 \pm 0.14$ & $4.6 \pm 0.9$ \\
\hline
\end{tabular}

Values are mean \pm SE. There are seven experiments in each group.

- Values that differ significantly from the base-line value before insulin infusion, as determined by Dunnett's test.

to have an antagonistic effect on the positive inotropic action of norepinephrine $(17,38)$.

The increases in cardiac output and heart rate during insulin infusion in normal dogs were associated with increases in left ventricular work, myocardial oxygen consumption, and left ventricular blood flow.
Similar findings during insulin hypoglycemia also have been reported by Hackel (39). These changes, however, did not occur in dogs pretreated with propranolol. Thus, it appears that the increase in myocardial blood flow produced by insulin is causally related to the increased myocardial metabolic demand, as car-

TABLE II

Effects of Insulin Euglycemia on Coronary Hemodynamics

\begin{tabular}{|c|c|c|c|c|c|}
\hline Insulin & $\begin{array}{l}\text { Left ventricular } \\
\text { blood flow }\end{array}$ & $\begin{array}{c}\text { Myocardial } \\
\mathrm{O}_{2} \text { extraction }\end{array}$ & $\begin{array}{l}\text { Myocardial } \mathrm{O}_{2} \\
\text { consumption }\end{array}$ & $\begin{array}{l}\text { Coronary vascular } \\
\text { resistance }\end{array}$ & $\begin{array}{l}\text { Left ventricular } \\
\text { work }\end{array}$ \\
\hline$m U / \mathrm{kg} / \min$ & $\mathrm{ml} / 100 \mathrm{~g} / \mathrm{min}$ & $\%$ & $\mathrm{ml} / 100 \mathrm{~g} / \mathrm{min}$ & $\begin{array}{c}m m \mathrm{Hg} /(\mathrm{ml} / 100 \\
\mathrm{g} / \mathrm{min})\end{array}$ & $\mathrm{kg} \cdot \mathrm{m} / \min$ \\
\hline
\end{tabular}

Group 4 No pretreatment

$\begin{array}{cccccc}0 & 92 \pm 11 & 77 \pm 3 & 10.7 \pm 1.2 & 1.31 \pm 0.12 & 5.9 \pm 0.7 \\ 4 & 118 \pm 15^{\circ} & 77 \pm 3 & 12.9 \pm 1.3^{\circ} & 1.11 \pm 0.14^{\circ} & 7.7 \pm 0.8^{\circ} \\ 8 & 120 \pm 12^{\circ} & 72 \pm 3 & 13.0 \pm 1.0^{\circ} & 1.12 \pm 0.12^{\circ} & 8.5 \pm 1.0^{\circ}\end{array}$

Group 5 Propranolol pretreatment

\begin{tabular}{llllll}
0 & $74 \pm 5$ & $80 \pm 2$ & $9.2 \pm 0.8$ & $1.60 \pm 0.15$ & $6.5 \pm 0.5$ \\
4 & $71 \pm 5$ & $84 \pm 1$ & $8.8 \pm 0.8$ & $1.72 \pm 0.18$ & $6.8 \pm 0.5$ \\
8 & $85 \pm 6$ & $84 \pm 2$ & $9.6 \pm 0.9$ & $1.48 \pm 0.13$ & $6.6 \pm 0.4$ \\
\hline
\end{tabular}

Values are mean $\pm \mathrm{SE}$. There are seven experiments in each group.

- = values that differ significantly from the base-line value before insulin infusion, as determined by Dunnett's test. 
TABLE III

Effects of Insulin Hypoglycemia on Myocardial Use of Glucose, Lactate, and Pyruvate

\begin{tabular}{|c|c|c|c|c|c|c|}
\hline \multirow[b]{2}{*}{ Insulin } & \multicolumn{2}{|c|}{ Glucose } & \multicolumn{2}{|c|}{ Lactate } & \multicolumn{2}{|c|}{ Pyruvate } \\
\hline & $\begin{array}{c}\text { Arterial } \\
\text { concentration }\end{array}$ & Utilization & $\begin{array}{c}\text { Arterial } \\
\text { concentration }\end{array}$ & Utilization & $\begin{array}{c}\text { Arterial } \\
\text { concentration }\end{array}$ & Utilization \\
\hline$\underset{\min }{\mathrm{mU} / \mathrm{kg} /}$ & $m M$ & $\mu \mathrm{mol} / 100 \mathrm{~g} / \mathrm{min}$ & $m M$ & $\mu \mathrm{mol} / 100 \mathrm{~g} / \mathrm{min}$ & $m M$ & $\mu \mathrm{mol} / 100 \mathrm{~g} / \mathrm{min}$ \\
\hline \multicolumn{7}{|c|}{ Group 1 No pretreatment } \\
\hline 0 & $4.0 \pm 0.2$ & $15.8 \pm 3.8$ & $2.22 \pm 0.40$ & $80 \pm 20$ & $0.24 \pm 0.03$ & $13 \pm 3$ \\
\hline 4 & $2.4 \pm 0.1^{\bullet}$ & $41.1 \pm 6.8^{\circ}$ & $2.76 \pm 0.43$ & $148 \pm 26^{\circ}$ & $0.26 \pm 0.02$ & $16 \pm 2$ \\
\hline 8 & $1.9 \pm 0.1^{\bullet}$ & $26.6 \pm 3.9$ & $2.88 \pm 0.27$ & $129 \pm 24^{\circ}$ & $0.30 \pm 0.02^{\circ}$ & $20 \pm 4^{\circ}$ \\
\hline \multicolumn{7}{|c|}{ Group 2 Propranolol pretreatment } \\
\hline 0 & $3.9 \pm 0.2$ & $16.7 \pm 1.8$ & $1.76 \pm 0.30$ & $59 \pm 11$ & $0.23 \pm 0.04$ & $11 \pm 2$ \\
\hline 4 & $2.1 \pm 0.2^{\circ}$ & $28.9 \pm 6.0$ & $1.35 \pm 0.22$ & $47 \pm 8$ & $0.19 \pm 0.02^{\circ}$ & $8 \pm 1$ \\
\hline 8 & $1.7 \pm 0.2^{\circ}$ & $25.9 \pm 6.6$ & $1.30 \pm 0.17$ & $43 \pm 8$ & $0.18 \pm 0.02^{\circ}$ & $7 \pm 2^{\circ}$ \\
\hline \multicolumn{7}{|c|}{ Group 3 Propranolol and phentolamine pretreatment } \\
\hline $\mathbf{0}$ & $3.8 \pm 0.3$ & $12.8 \pm 3.1$ & $1.98 \pm 0.30$ & $77 \pm 6$ & $0.26 \pm 0.02$ & $10 \pm 1$ \\
\hline 4 & $2.0 \pm 0.3^{\circ}$ & $29.3 \pm 5.8^{\circ}$ & $1.76 \pm 0.23$ & $80 \pm 13$ & $0.22 \pm 0.02$ & $9 \pm 2$ \\
\hline 8 & $1.9 \pm 0.4^{\circ}$ & $23.8 \pm 3.1$ & $1.77 \pm 0.33$ & $63 \pm 11$ & $0.19 \pm 0.02^{\circ}$ & $5 \pm 1^{\circ}$ \\
\hline
\end{tabular}

Values are mean $\pm \mathrm{SE}$. There are seven experiments in each group.

- = values that differ significantly from the base-line value before insulin infusion, as determined by Dunnett's test.

diac work is increased by beta adrenergic stimulation during insulin infusion.

The increase in myocardial oxygen consumption was attended by an increase in carbohydrate use in groups 1 and 4 . In group 1 , insulin facilitated the utilization of glucose by the heart until low levels of arterial glu- cose were reached; at that time, lactate and pyruvate use increased. When increased myocardial oxygen consumption was met with increased glucose utilization (group 4), pyruvate utilization remained relatively unchanged. In groups, 2, 3, and 5, when glucose utilization was increased without a concomitant rise in

TABLE IV

Effects of Insulin Euglycemia on Myocardial Use of Glucose, Lactate, and Pyruvate

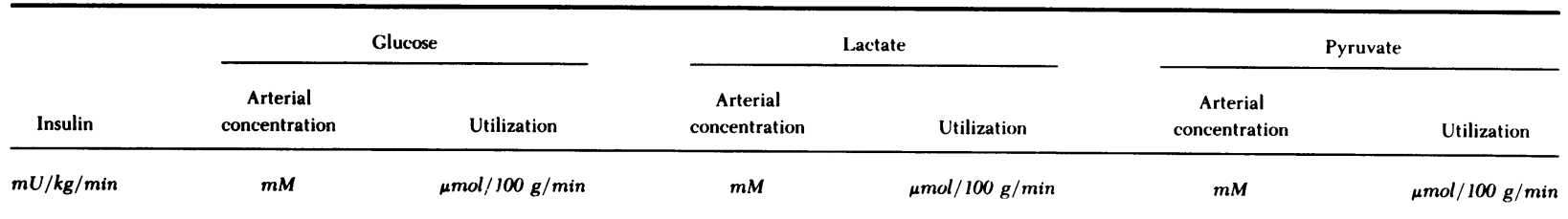

Group 4 No pretreatment

$\begin{array}{lllllll}0 & 4.1 \pm 0.3 & 16.2 \pm 3.7 & 2.02 \pm 0.26 & 77 \pm 11 & 0.24 \pm 0.03 & 14 \pm 3 \\ 4 & 3.9 \pm 0.2 & 39.8 \pm 6.3^{\circ} & 1.95 \pm 0.25 & 106 \pm 13^{\circ} & 0.23 \pm 0.03 & 14 \pm 3 \\ 8 & 4.2 \pm 0.2 & 37.0 \pm 6.1^{\circ} & 1.78 \pm 0.28 & 104 \pm 15^{\circ} & 0.20 \pm 0.02 & 10 \pm 3\end{array}$

Group 5 Propranolol pretreatment

\begin{tabular}{llllllr}
0 & $3.9 \pm 0.1$ & $16.5 \pm 5.1$ & $1.65 \pm 0.19$ & $78 \pm 14$ & $0.30 \pm 0.02$ & $11 \pm 2$ \\
4 & $3.8 \pm 0.1$ & $32.4 \pm 4.6^{\circ}$ & $1.30 \pm 0.21$ & $59 \pm 12$ & $0.17 \pm 0.02^{\circ}$ & $5 \pm 1^{\circ}$ \\
8 & $3.9 \pm 0.1$ & $29.6 \pm 4.5^{\circ}$ & $1.45 \pm 0.31$ & $62 \pm 12$ & $0.18 \pm 0.02^{\circ}$ & $6 \pm 1^{\circ}$ \\
\hline
\end{tabular}

Values are mean $\pm \mathrm{SE}$. There are seven experiments in each group.

- = values that differ significantly from the base-line value before insulin infusion, as determined by Dunnett's test. 
TABLE V

Effects of Insulin Infusion on Regional Organ Blood Flow in Group 1 Animals

\begin{tabular}{lcccc}
\hline & \multicolumn{3}{c}{ Insulin infusion } \\
\cline { 3 - 4 } \multicolumn{1}{c}{ Organ } & Control & 4 & 8 & $\begin{array}{c}\text { Insulin infusion } \\
\text { plus glucose }\end{array}$ \\
\hline & \multicolumn{4}{c}{$\mathrm{mU} / \mathrm{kg} / \mathrm{min}$} \\
Brain & $61 \pm 6$ & $57 \pm 8$ & $55 \pm 6$ & $63 \pm 8$ \\
Lungs (bronchial) & $54 \pm 8$ & $37 \pm 4^{\bullet}$ & $20 \pm 2^{\bullet}$ & $38 \pm 2^{\bullet}$ \\
Right ventricle & $67 \pm 8$ & $83 \pm 17$ & $96 \pm 12^{\bullet}$ & $112 \pm 10^{\circ}$ \\
Left ventricle & $103 \pm 12$ & $124 \pm 23$ & $141 \pm 20^{\bullet}$ & $161 \pm 10^{\circ}$ \\
Adrenal glands & $248 \pm 26$ & $270 \pm 33$ & $346 \pm 38^{\bullet}$ & $242 \pm 26$ \\
Kidneys & $377 \pm 49$ & $363 \pm 35$ & $348 \pm 41$ & $322 \pm 20$ \\
Liver (hepatic) & $25 \pm 7$ & $27 \pm 7$ & $22 \pm 6$ & $26 \pm 7$ \\
Spleen & $221 \pm 34$ & $239 \pm 32$ & $213 \pm 37$ & $182 \pm 31$ \\
Stomach & $58 \pm 21$ & $51 \pm 21$ & $59 \pm 21$ & $38 \pm 9$ \\
Small intestine & $42 \pm 9$ & $37 \pm 7$ & $42 \pm 10$ & $38 \pm 6$ \\
Large intestine & $68 \pm 14$ & $66 \pm 13$ & $66 \pm 15$ & $73 \pm 14$ \\
Pancreas & $52 \pm 12$ & $42 \pm 10$ & $50 \pm 16$ & $52 \pm 12$ \\
Femoral muscle & $3 \pm 1$ & $6 \pm 1^{\bullet}$ & $7 \pm 2^{\bullet}$ & $8 \pm 3^{\bullet}$ \\
Skin & $3 \pm 1$ & $3 \pm 1$ & $3 \pm 1$ & $3 \pm 1$ \\
Femur & $8 \pm 2$ & $7 \pm 1$ & $8 \pm 3$ & $10 \pm 3$ \\
\hline
\end{tabular}

Values are mean $\pm \mathrm{SE} \mathrm{ml} / 100 \mathrm{~g} / \mathrm{min} ; \boldsymbol{n}=7$.

- = values that differ significantly from the control value before insulin infusion, as determined by Dunnett's test. myocardial oxygen consumption, pyruvate utilization actually fell. Arterial pyruvate increased significantly during insulin hypoglycemia (group 1). Arterial lactate also showed a tendency to increase in this group, although the change was not statistically significant. Other groups did not exhibit an increase in either lactate or pyruvate concentration in arterial blood. Most likely, the increase in arterial substrate concentration in group 1 was caused by the beta receptor-mediated metabolic effect of epinephrine.

Vascular effects of insulin. Mean aortic blood pressure did not change during insulin hypoglycemia, but rose during insulin infusion when the blood glucose was kept from falling. The difference between the two groups probably was related in part to the selective release of norepinephrine and the predominant alpha adrenergic action of this hormone in the latter group. The absence of a pressor response during insulin hypoglycemia might be attributed to the prominent concomitant vasodilation. Vasodilation could be the result of reflex sympathetic withdrawal secondary to the widened arterial pulse pressure. It also could be produced by the direct vasodilator action of epinephrine whose concentration was also increased. That catecholamines play an important role in mediating this
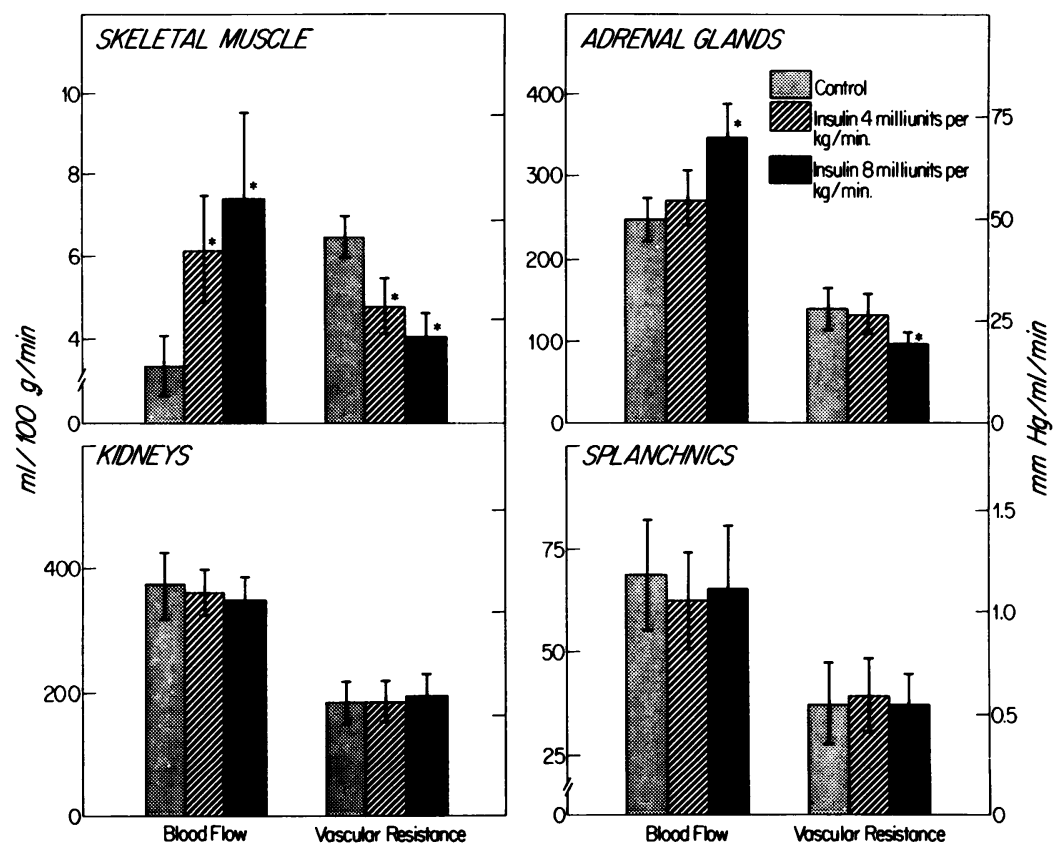

Figure 7 Effects of insulin on skeletal muscle, adrenal, renal, and splanchnic blood flows and vascular resistances in seven normal dogs (Group 1). Bars show SE. Vascular resistance was calculated for the whole organ except in the case of femoral muscle in which $100 \mathrm{~g}$ tissue mass was used. ${ }^{\bullet}=$ values that are significantly different from the control value before insulin infusion. 

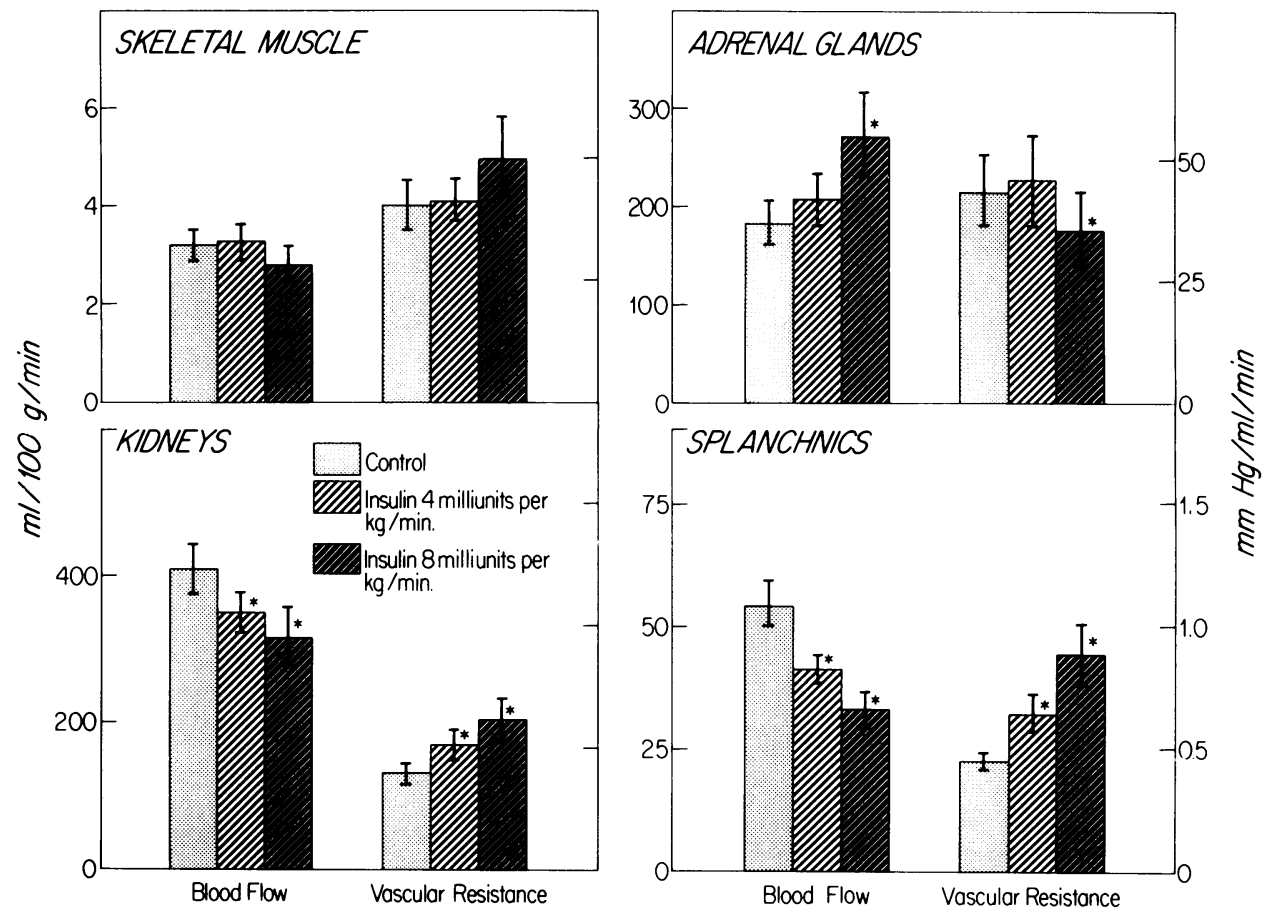

Figure 8 Effects of insulin on skeletal muscle, adrenal, renal, and splanchnic blood flows, and vascular resistances in seven dogs that had been pretreated with- propranolol (group 2). See legend to Fig. 7 for additional details.
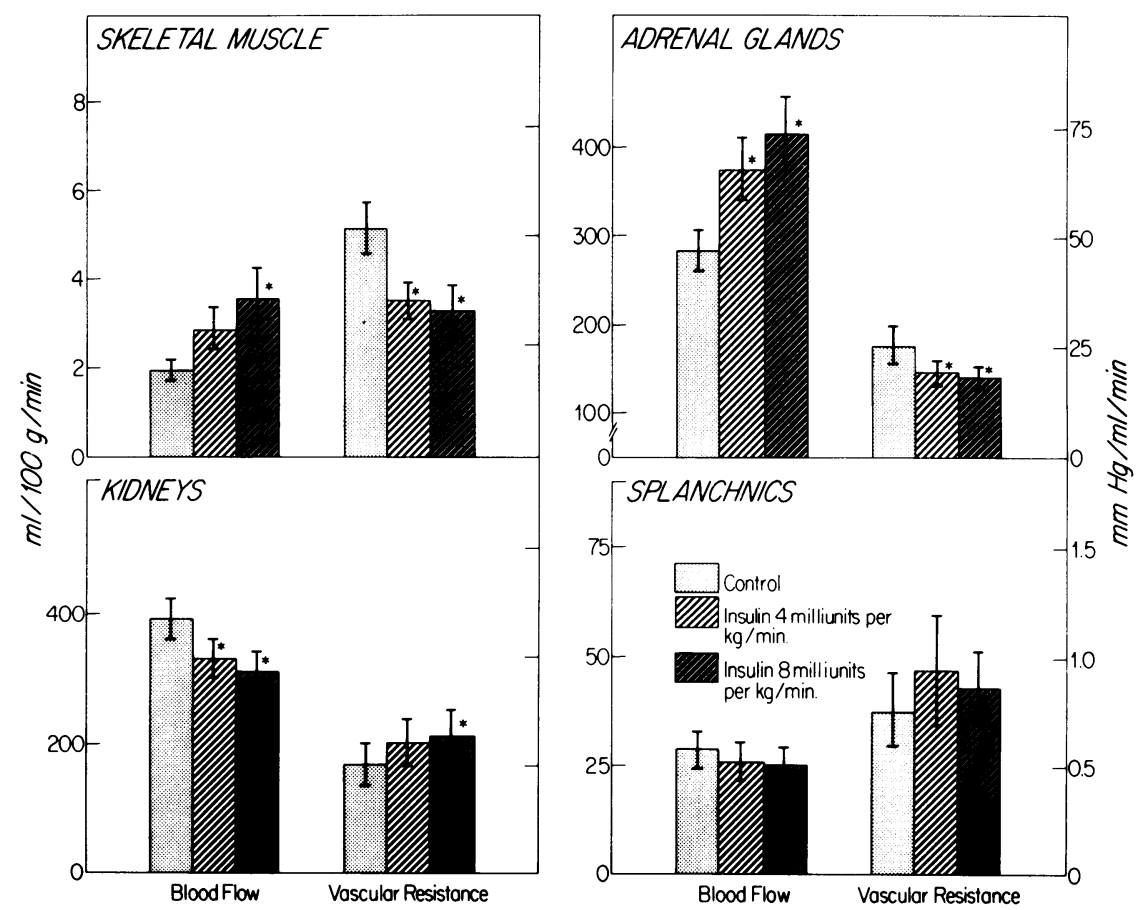

Figure 9 Effects of insulin on skeletal muscle, adrenal, renal, and splanchnic blood flows and vascular resistances in seven dogs that had been pretreated with both propranolol and phentolamine (group 3). See legend to Fig. 7 for additional details. 

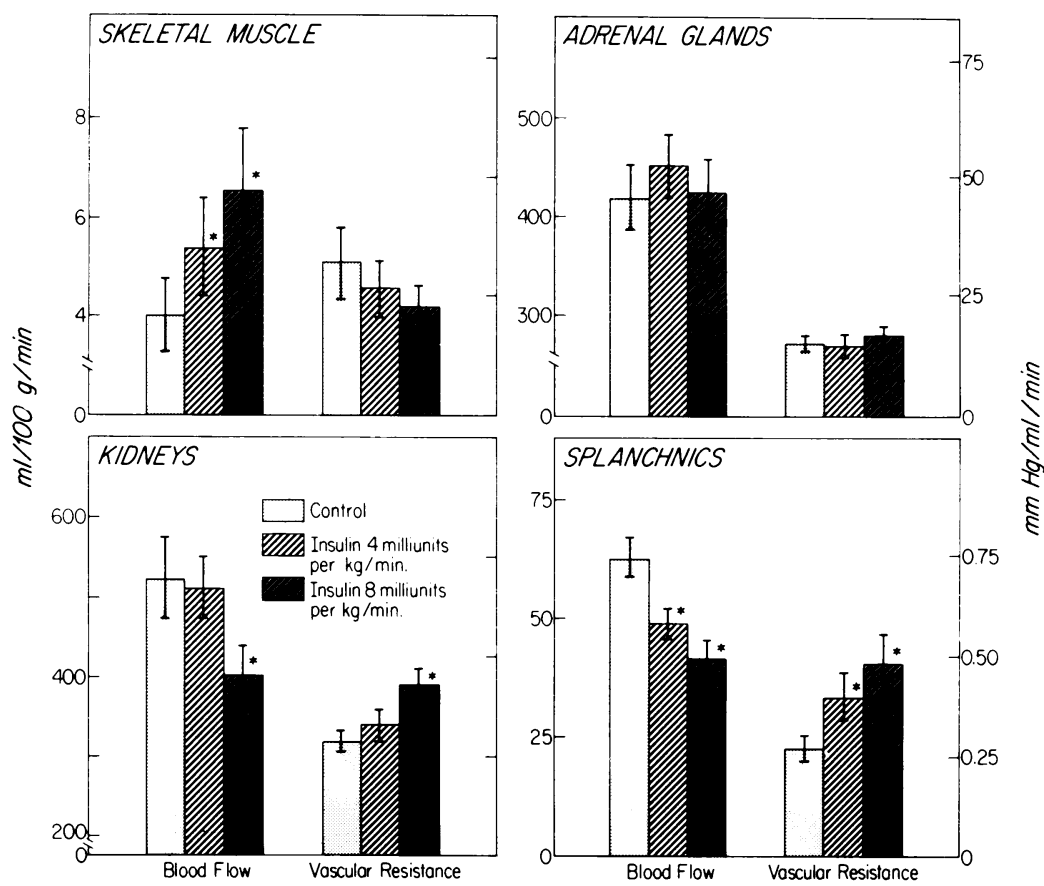

Figure 10 Effects of insulin on skeletal muscle, adrenal, renal, and splanchnic blood flows, and vascular resistances in seven normal dogs whose blood glucose was maintained in euglycemic range by a glucose-clamp technique (group 4). See legend to Fig. 7 for additional details.
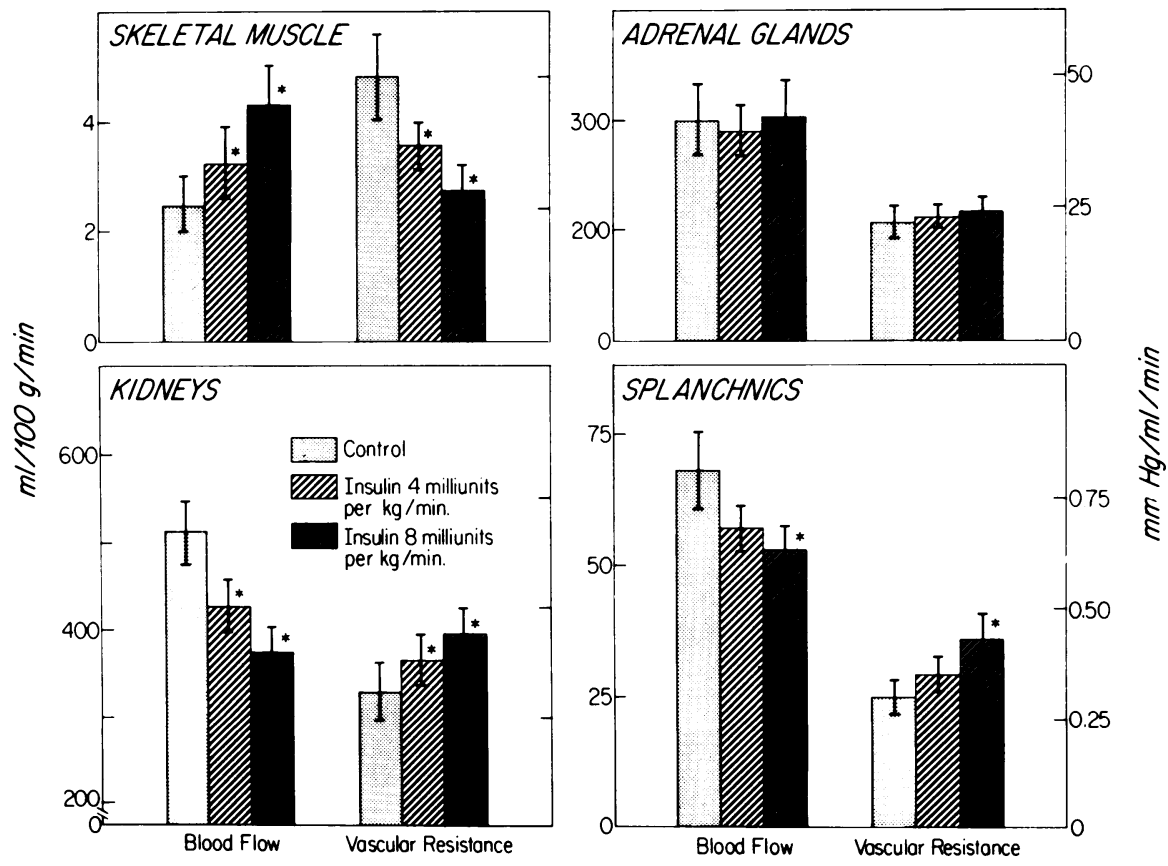

Figure 11 Effects of insulin on skeletal muscle, adrenal, renal, and splanchnic blood flows and vascular resistances in seven dogs that had been pretreated with propranolol and were kept euglycemic during insulin infusion (group 5). See legend to Fig. 7 for additional details. 
response is suggested by the finding that propranolol pretreatment abolished the increase in skeletal muscle blood flow and unmasked a pressor effect of insulin in group 2. This pressor effect, which probably was caused by the unopposed alpha receptor-mediated vasoconstriction, did not occur in dogs pretreated with both propranolol and phentolamine (group 3). Alpha adrenergic receptor-mediated vasoconstriction probably was also present during insulin infusion in euglycemic animals pretreated with propranolol (group 5), as shown by the slight rise in total peripheral vascular resistance (Fig. 4) and increases in organ vascular resistances (Fig. 11). However, the increase in total systemic resistance was less marked than in group 2 hypoglycemic animals with beta receptor blockade (Fig. 2 ), probably because catecholamine release was less prominent during euglycemia. Also in group 5 , vasodilation occurred in skeletal muscle during insulin euglycemia as renal and splanchnic vascular resistances were increased; as a result, mean aortic blood pressure did not rise.

The persistent increase in skeletal muscle flow produced by insulin in group 3 suggests that insulin could produce a vasodilator effect on the skeletal muscle vasculature independent of the sympathetic nervous system. This probably is related to the metabolic effects of insulin on tissue metabolism and ion fluxes (40). Human studies also have shown that the effects of insulin on the skeletal muscle flow does not entirely depend on the integrity of the sympathetic nervous system, because they are not abolished by either adrenalectomy or by cervicodorsal sympathectomy $(41$, 42). A cholinergic mechanism has been postulated for the vasodilator effect of insulin in the forearm, but the increase in forearm blood flow is not completely abolished by intrabrachial administration of atropine (43).

The vasodilator effect of insulin probably is responsible for the progressive fall in supine arterial blood pressure after insulin administration in sympathectomized patients (11). Arterial pressure also falls, especially in the erect position, after insulin administration in diabetic patients with either abnormal baroreceptor reflexes (44) or an autonomic neuropathy (45). This hypotensive effect of insulin may be unrelated to hypoglycemia, and may account for some episodes of sudden loss of consciousness, usually attributed to hypoglycemia (45).

Adrenal blood flow increased and vascular resistance decreased during insulin hypoglycemia, accompanied by a substantial elevation of plasma catecholamines (group 1). However, when euglycemia was maintained, neither adrenal blood flow nor plasma epinephrine increased, and only a small increase in plasma norepinephrine occurred (group 4). The results suggest that release of catecholamines from the adrenal medulla may be closely coupled with increases in adrenal blood flow, but the mechanism for this coupling mechanism remains to be clarified.

Neither blood flow nor vascular resistance changed significantly in the splanchnic circulation in normal dogs during insulin hypoglycemia (group 1). This finding is compatible with balanced alpha receptor-mediated vasoconstriction and beta receptor-mediated vasodilator effects. However, in groups 2, 4, and 5, splanchnic vasoconstriction and a fall in splanchnic blood flow were observed, suggesting predominant alpha receptor-mediated vasoconstriction. In group 3 with both alpha and beta receptor blockade, no change was noted in vascular resistance or blood flow to any of the splanchnic organs during insulin hypoglycemia. These results suggest that insulin has no direct actions on the vascular tone of the splanchnic circulation.

Renal blood flow did not change significantly in group 1, but was decreased in four other groups during insulin infusion. Although alpha receptor-mediated vasoconstriction might have contributed to the decrease in renal blood flow in groups 2,4 , and 5 , the persistent increase in renal vascular resistance in group 3 suggests that insulin hypoglycemia may produce renal vasoconstriction by a mechanism unrelated to the sympathetic nervous system. Otsuka et al. (46) have shown that insulin hypoglycemia causes an increase in plasma renin activity, and further suggested that this effect is mediated in part via insulin-induced hypokalemia. Thus it is possible that the increase in renal vascular resistance in alpha and beta receptor-blocked animals might have resulted from the release of renin and increased local production of angiotensin. Renal plasma flow and glomerular filtration rate have been shown to decrease after intravenous injection of insulin in juvenile diabetics (47), but it is not known whether these changes are related to sympathetic vasoconstriction or to local production of renin and angiotensin.

\section{ACKNOWLEDGMENTS}

The authors thank Dr. Neil Ruderman for his critical review of this manuscript, and Samuel Rivers, Song Que Lee, Debra Ginsburg, Alexander W. Tsui, Chhanda Panda, and Margaret Bresnahan for their technical assistance. The following chemicals were generously supplied by pharmaceutical companies: indocyanine green (Cardio-Green) by Hynson, Westcott \& Dunning, Inc., Baltimore, MD; insulin by Dr. John A. Galloway, Lilly Research Laboratories, Indianapolis, IN; phentolamine $\mathrm{HCl}$ (Regitine) by Ciba Pharmaceutical Company, Division of Ciba-Geigy Corp., Summit, NJ; propranolol $\mathrm{HCl}$ (Inderal) by Ayerst, McKenna, \& Harrison Ltd., Montreal, Canada.

This study was supported in part by U. S. Public Health Service grants HL-24214, HL-17403, and HL-14646. 


\section{REFERENCES}

1. Ernstene, A. C., and M. D. Altschule. 1931. The effect of insulin hypoglycemia on the circulation. J. Clin. Invest. 10: 521-528.

2. DiSalvo, R. J., W. L. Bloom, A. A. Brust, R. W. Ferguson, and E. B. Ferris. 1956. A comparison of the metabolic and circulatory effects of epinephrine, norepinephrine and insulin hypoglycemia with observations on the influence of autonomic blocking agents. J. Clin. Invest. 35: 568-577.

3. Page, M. McB., R. B. W. Smith, and P. J. Watkins. 1976. Cardiovascular effects of insulin. Br. Med. J. 1: 430-432.

4. Arner, B., P. Hedner, T. Karlefors, and W. Westling. 1963. Haemodynamic changes and adrenal function in man during induced hypoglycemia. Acta Endocrinol. 44: 430-442.

5. Dosekun, F. O., J. Grayson, and D. Mendel. 1960. The measurement of metabolic and vascular responses in liver and muscle with observations on their responses to insulin and glucose. J. Physiol. (Lond.). 150: 581-606.

6. Abramson, D. I., N. Schkloven, M. N. Margolis, and I. A. Mirsky. 1939. Influence of massive doses of insulin on peripheral blood flow in man. Am. J. Physiol. 128: 124-132.

7. Allwood, M. J., I. Birchall, and J. S. Staffurth. 1958. Circulatory changes in the forearm during insulin hypoglycaemia studied by regional ${ }^{24} \mathrm{Na}$ clearance and by plethysmography. J. Physiol. (Lond.). 143: 332-342.

8. Allwood, M. J., H. Hensel, and J. Papenberg. 1959. Muscle and skin blood flow in the human forearm during insulin hypoglycaemia. J. Physiol. (Lond.). 147: 269273.

9. Dosekun, F. O. 1962. The measurement of metabolic and vascular responses in human skeletal muscle with observations on its responses to insulin and glucose. Clin Sci. (Lond.). 22: 287-294.

10. Cannon, W. B., M. A. McIver, and S. W. Bliss. 1924. Studies on the conditions of activity in endocrine glands. XIII. A sympathetic and adrenal mechanism for mobilizing sugar in hypoglycemia. Am. J. Physiol. 69: 46-66.

11. French, E. B., and R. Kilpatrick. 1955. Role of adrenaline in hypoglycaemic reactions in man. Clin. Sci. (Lond.). 14: 639-651.

12. Wallace, J. M., and W. R. Harlan. 1965. Significance of epinephrine in insulin hypoglycemia in man. Am. J. Med. 38: 531-539.

13. Goldfien, A., R. Moore, S. Zileli, L. L. Havens, L. Boling, and G. W. Thorn. 1961. Plasma epinephrine and norepinephrine levels during insulin-induced hypoglycemia in man. J. Clin. Endocrinol. 21: 296-304.

14. Christensen, N. J., K. G. M. M. Alberti, and O. Brandsborg. 1975. Plasma catecholamines and blood substrate concentrations: studies in insulin induced hypoglycaemia and after adrenaline infusions. Eur. J. Clin. Invest. 5: 415-423.

15. Christensen, N. J. 1979. Plasma noradrenaline and adrenaline measured by isotope-derivative assay. Dan. Med. Bull. 26: 17-36.

16. Rowe, J. W., J. B. Young, K. L. Minaker, A. L. Stevens, J. Pallotta, and L. Landsberg. 1981. Effect of insulin and glucose infusions on sympathetic nervous system activity in normal man. Diabetes. 30: 219-225.

17. Lee, J. C., and S. E. Downing. 1976. Effects of insulin on cardiac muscle contraction and responsiveness to norepinephrine. Am. J. Physiol. 230: 1360-1365.
18. Rieker, R. P., J. C. Lee, and S. E. Downing. 1975. Inotropic action of insulin on piglet heart. Yale J. Biol. Med. 48: 353-360.

19. Downing, S. E., J. C. Lee, and R. P. Rieker. 1977. Mechanical and metabolic effects of insulin on newborn lamb myocardium. Am. J. Obstet. Gynecol. 127: 647656.

20. Lucchesi, B. R., M. Medina, and F. J. Kniffen. 1972. The positive inotropic action of insulin in the canine heart. Eur. J. Pharmacol. 18: 107-115.

21. Davidson, D. M., J. W. Covell, C. I. Malloch, and J. Ross, Jr. 1974. Factors influencing indices of left ventricular contractility in the conscious dog. Cardiovasc. Res. 8: 299-312

22. Liang, C., and J. M. Lowenstein. 1978. Metabolic control of the circulation. Effects of acetate and pyruvate. $J$. Clin. Invest. 62: 1029-1038.

23. Rudolph, A. M., and M. A. Heymann. 1967. The circulation of the fetus in utero. Methods for studying distribution of blood flow, cardiac output and organ blood flow. Circ. Res. 21: 163-184.

24. Peuler, J. P., and G. A. Johnson. 1977. Simultaneous single isotope radioenzymatic assay of plasma norepinephrine, epinephrine and dopamine. Life Sci. 21: 625636.

25. Huckabee, W. E. 1956. Control of concentration gradients of pyruvate and lactate across cell membranes in blood. J. Appl. Physiol. 9: 163-170.

26. Friedland, I. M., and L. S. Dietrich. 1961. A rapid enzymic determination of $\mathrm{L}(+)$-lactic acid. Anal. Biochem. 2: $390-392$

27. Defronzo, R. A., J. D. Tobin, and R. Andres. 1979. Glucose clamp technique: a method for quantifying insulin secretion and resistance. Am. J. Physiol. 237: E214E223.

28. Winer, B. J. 1971. Statistical Principles in Experimental Design. 2nd edition. McGraw-Hill Book Co., Inc., New York. 261-300.

29. Dunnett, C. W. 1964. New tables for multiple comparisons with a control. Biometrics. 20: 482-491.

30. Niijima, A. 1975. The effect of 2-deoxy-D-glucose and D-glucose on the efferent discharge rate of sympathetic nerves. J. Physiol. (Lond.). 251: 231-243.

31. Himsworth, R. L. 1970. Hypothalamic control of adrenaline secretion in response to insufficient glucose. $J$. Physiol. (Lond.). 206: 411-417.

32. Gundersen, H. J. G., and N. J. Christensen. 1977. Intravenous insulin causing loss of intravascular water and albumin and increased adrenergic nervous activity in diabetics. Diabetes. 26: 551-557.

33. Parving, H. H., I. Noer, T. Deckert, and N. A. Lassen. 1979. Intravenous insulin has no effect on transcapillary escape rate of albumin and on plasma volume in shortterm juvenile diabetics. Diabetes. 28: 282-286.

34. Pereda, S. A., J. W. Eckstein, and F. M. Abboud. 1962 Cardiovascular responses to insulin in the absence of hypoglycemia. Am. J. Physiol. 202: 249-252.

35. Liang, C., and W. B. Hood, Jr. 1973. Comparison of cardiac output responses to 2,4-dinitrophenol-induced hypermetabolism and muscular work. J. Clin. Invest. 52: 2283-2292.

36. Therminarias, A., M. F. Chirpaz, A. Lucas, and M. Tanche. 1979. Calorigenic effect of insulin in hypothermic dogs. J. Appl. Physiol. Respir. Environ. Exercise Physiol. 47: 342-346.

37. Regan, T. J., M. J. Frank, P. H. Lehan, and H. K. Hel- 
lems. 1963. Relationship of insulin and strophanthidin to myocardial metabolism and function. Am. J. Physiol. 205: 790-794.

38. Nudel, D. B., J. C. Lee, and S. E. Downing. 1977. Reciprocal inhibition of cardiac responses to norepinephrine and insulin. Am. J. Physiol. 233: H665-H669.

39. Hackel, D. B. 1960 . Effect of insulin on cardiac metabolism of intact normal dogs. Am. J. Physiol. 199: 11351138.

40. Zierler, K. L. 1972. Insulin, ions, and membrane potentials. In Handbook of Physiology. Section 7. Endocrinology. D. F. Steiner and N. T. Freinkel, editors. Am. Physiol. Soc., Wash., D.C. 1: 347-378.

41. Allwood, M. J., J. Ginsburg, and A. Paton. 1957. The effect of insulin hypoglycaemia on blood flow in intact and sympathectomized extremities in man. J. Physiol. (Lond.). 139: 97-107.

42. Ginsburg, J., and A. Paton. 1956. Effects of insulin after adrenalectomy. Lancet. II: 491-494.
43. Allwood, M. J., and J. Ginsburg. 1959. The effect of intra-arterial atropine on blood flow in the hand and forearm during insulin hypoglycaemia. J. Physiol. (Lond.). 149: 486-493.

44. Miles, D. W., and C. J. Hayter. 1968. The effect of intravenous insulin on the circulatory responses to tilting in normal and diabetic subjects with special reference to baroreceptor reflex block and atypical hypoglycaemia reactions. Clin. Sci. 34: 419-430.

45. Page, M. McB., and P. J. Watkins. 1976. Provocation of postural hypotension by insulin in diabetic autonomic neuropathy. Diabetes. 25: 90-95.

46. Otsuka, K., T. A. Assaykeen, A. Goldfien, and W. F. Ganong. 1970. Effect of hypoglycemia on plasma renin activity in dogs. Endocrinology. 87: 1306-1317.

47. Morgensen, C. E., N. J. Christensen, and H. J. G. Gundersen. 1978. The acute effect of insulin on renal haemodynamics and protein excretion in diabetics. Diabetologia. 15: 153-157. 